\title{
APLICATION OF ATUNG (Parinarium glaberimum, HASSK) IN HANDLING OF FRESH PELAGIC FISH
}

\section{Trijunianto Moniharapon 1) and Angcivioletta Moniharapon ${ }^{2)}$}

\author{
1)Department of Fish Processing Technology, Faculty of Fisheries and Marine Science, \\ Pattimura University, Ambon, Indonesia. 08124486977 trij09@yahoo.com \\ 2)Researcher of Balai Riset dan Standarisasi Industri Manado, Manado, Indonesia. \\ 085298793027,moniharaponletta@yahoo.co.id
}

\begin{abstract}
Atung plant (Parinarium glaberimum, HASSK) is endemic in Mollucas. Fruit of Atung have been used for hundred of years by the local fishermen when they go fishing. Efforts to preserved fresh food (especially fish) were continually pursue by using natural preserver which contained bioactive compound as antibacteria. The aim of the study was to get information on the quality (organoleptic, chemical, and microbiological) of post harvested using fish kept in atung powder and atung solution. Three kind of pelagic fish were used, namely; Layang (Decapterus sp), Tongkol (Euthynus sp) and Kembung (Restligger sp). The fishes were kept in 0,3\% powder atung $(\mathrm{W} / \mathrm{W})$ and $20 \%$ atung solution $(\mathrm{V} / \mathrm{V})$, with shelf-life of freshness of $0,4,8,12,16$, and 20 hours. Sensory quality test was conducted by using descriptive test with scale ranged from 1 - 9. Quality parameter observed were the appearance, odor, texture, TVB (total volatile base), $\mathrm{pH}$ and TPC (total plate count). The results showed that quality of post harvested fresh fish kept in atung was the best treatment and with longer shelf life of freshness; i.e. 21 hours (20 th hour) (Kembung and Tongkol), while layang fish was 17 hours ( 16 th hour). In other hand, the treatment without atung (control) was 9 hours ( 8 th hour). Atung fruits were more practical, efficient than the treatment without atung, to be used as an alternative preservative by the sea-boarding fishermen.
\end{abstract}

Key words : endemic, atung, shelf-life, fresh of pelagic fish.

\section{INTRODUCTION}

Fresh fish handling practices for this is to use ice and no ice. Fresh fish is handled from pelagic fish such as the small like Tembang, Kembung and Layang; and medium like as well as large like Tongkol and Skipjack. Fishing is done by the "purse seine" fishermen and fishing "pole and line". Handling of fish without the use of ice caused the decline of the quality of fish. One of the natural ingredisnts is the use of fruit instead of Atung. Use Atung fruit seeds as food preservatives have been shown. Atung fraction containing bioactive components can kill pathogenic bacteria and food destroyer (Moniharapon, 1998).

Purification and identification of antibacterial components of seed atung been done catching It turns out that the bioactive components was aselac acid. Aselac acid can kill pathogens and destroyer of food, such as: Staphylococcus aureus, Salmonella enteritidis, Salmonella typhimurium, Bacillus subtilis, Micrococcus luteus, Enterococcus faecalis, Escherichia coli B dan C serta Pseudomonas aeruginosa (Moniharapon, 2004 ; 2005a). Application use of Atung on Windu shrimp handling can extend the life of a 17 hours freshness (Moniharapon, 1993), where as in handling several types of reef fish after catching it can be extended to 36 
hours of freshness (Moniharapon, 2005b). The research objective was to determine the quality of some types of fish pelagic fishing with the use of fresh post atung preparations.

\section{METHODS}

This research was conducted with the experimental method. Experiments using 3\% of atung powder, $20 \%$ of atung solution and control (without atung). Observation time consist of 6 levels with an interval of 4 hours. Analysis of the quality of fresh fish include: organoleptic test (appearance, odor and texture), chemical (ph and TVB) . and microbiology (TPC).

\section{RESULTS AND DISCUSSION}

The size and weight of each type of fish used are presented in Tabel 1.

Tabel 1. Size and Weight of Layang fish, Tongkol and Kembung.

\begin{tabular}{|c|c|c|c|c|}
\hline \multirow{2}{*}{ Fish kind } & \multicolumn{3}{|c|}{ Size $(\mathrm{cm})$} & \multirow{2}{*}{$\begin{array}{c}\text { Average } \\
\text { Weight(g) }\end{array}$} \\
\hline & Length & Width & Height & \\
\hline Layang & $18,5-19,2$ & $3,2-3,5$ & $2,7-3,1$ & 85 \\
\hline Tongkol & $22,2-23,4$ & $4,2-4,7$ & $3,6-4,1$ & 150 \\
\hline Kembung & $16,2-17,1$ & $4,5-4,7$ & $2,8-3,1$ & 100 \\
\hline
\end{tabular}

From the measurement and weighing. Layang (Decapterus sp) and Kembung (Rastreligger kanagurta) include fish pelagic were small, where as Tongkol (Euthynus sp) including pelagic fish of medium size. Fresh fish quality test results (1 hour post-catch) against Layang, Tongkol and Kembung are presented in Table 2, 3 and 4, while the deterioration in organoleptic observation presented in Table 1, 2 and 3.

Table 2. Analisys of Quality of Layang Fish

\begin{tabular}{cccccccc}
\hline Treatment & $\begin{array}{c}\text { Observation } \\
\text { (Hour) }\end{array}$ & $\mathrm{pH}$ & $\begin{array}{c}\text { TVB } \\
(\mathrm{mgN} \%)\end{array}$ & $\begin{array}{c}\text { TPC } \\
(\log \mathrm{X})\end{array}$ & $\begin{array}{c}\text { Appea } \\
\text { rance }\end{array}$ & odor & Texture \\
\hline \multirow{4}{*}{ Control } & 0 & 6,08 & 10,2 & 3,22 & 9.0 & 9,0 & 9,0 \\
& 4 & 6,13 & 13,4 & 4,10 & 7,2 & 7,0 & 7,2 \\
& 8 & 6,37 & 19,5 & 5,02 & 6,1 & 5,9 & 6,1 \\
& 12 & 6,53 & 32,7 & 5,82 & 4,6 & 4,4 & 4,7 \\
\hline \multirow{4}{*}{ Atung } & 0 & 6,08 & 10,2 & 3,22 & 9,0 & 9,0 & 9,0 \\
Powder & 4 & 6,11 & 11,6 & 3,70 & 7,6 & 7,7 & 7,8 \\
& 8 & 6,15 & 14,8 & 4,17 & 6,5 & 6,7 & 6,5 \\
& 12 & 6,30 & 18,8 & 5,20 & 5,9 & 6,1 & 6,1 \\
& 16 & 6,35 & 23,1 & 5,67 & 5,3 & 5,6 & 5,5 \\
& 20 & 6,48 & 33,4 & 5,77 & 4,4 & 4,3 & 4,5 \\
\hline \multirow{4}{*}{ Atung } & 0 & 6,08 & 10,2 & 3,22 & 9,0 & 9,0 & 9,0 \\
Solution & 4 & 6,11 & 11,1 & 3,59 & 7,7 & 7,9 & 7,9 \\
& 8 & 6,17 & 13,6 & 4,20 & 6,7 & 6,9 & 7,1 \\
& 12 & 6,31 & 17,6 & 5,04 & 6,1 & 6,2 & 6,4 \\
& 16 & 6,34 & 22,2 & 5,52 & 5,5 & 5,7 & 5,7 \\
& 20 & 6,40 & 28,8 & 5,62 & 4,6 & 4,5 & 4,5 \\
\hline
\end{tabular}



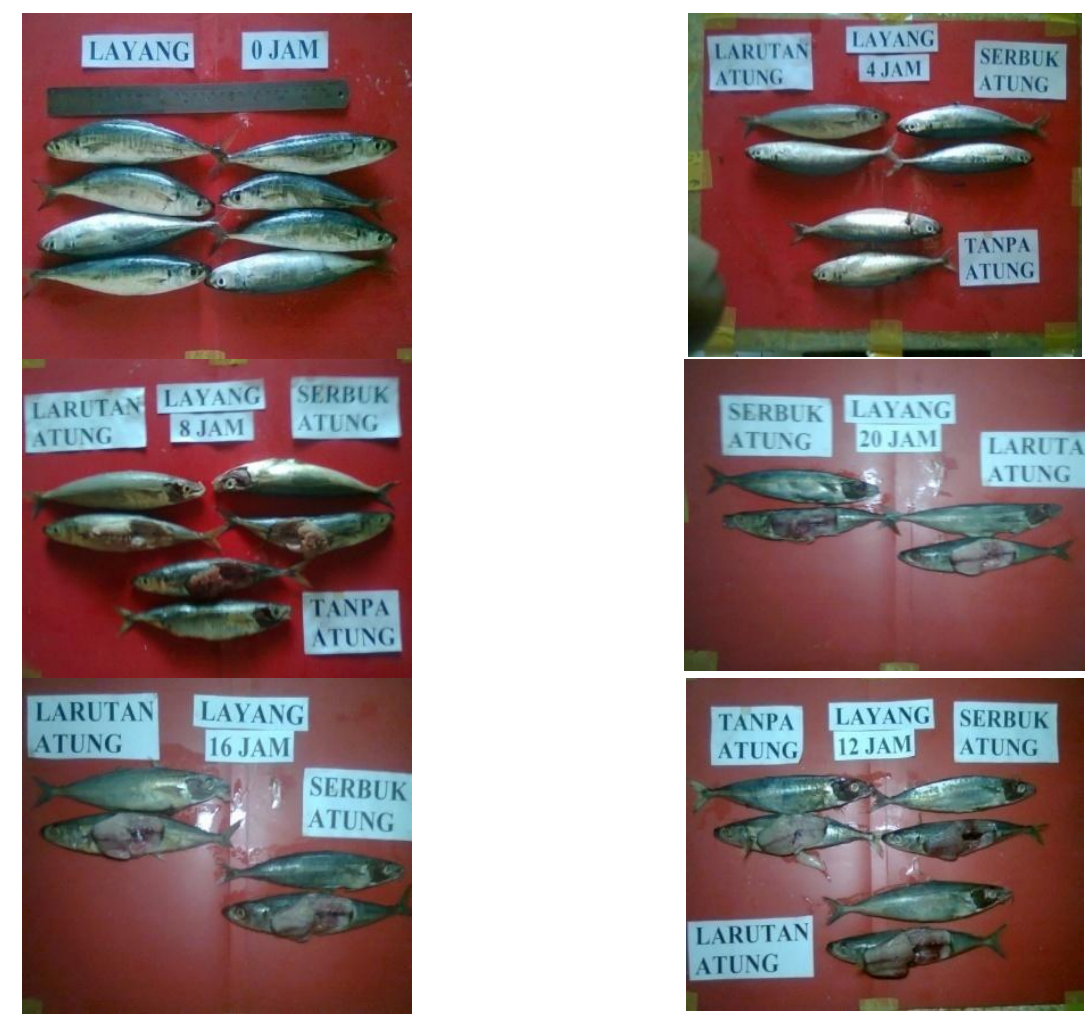

Figure. 1. Deterioration of Quality of Layang Fish (Organoleptic Assay)

Table 2. Analysis of Quality of Tongkol Fish

\begin{tabular}{cccccccc}
\hline Treatment & $\begin{array}{c}\text { Observation } \\
\text { (Hour) }\end{array}$ & $\mathrm{pH}$ & $\begin{array}{c}\text { TVB } \\
(\mathrm{mgN} \%)\end{array}$ & $\begin{array}{c}\text { TPC } \\
(\log \mathrm{X})\end{array}$ & $\begin{array}{c}\text { Appea } \\
\text { rance }\end{array}$ & odor & Texture \\
\hline \multirow{4}{*}{ Control } & 0 & 6,15 & 9,6 & 3,36 & 9.0 & 9,0 & 9,0 \\
& 4 & 6,27 & 15,9 & 4,04 & 7,5 & 7,4 & 7,6 \\
& 8 & 6,40 & 19,3 & 4,90 & 6,2 & 6,0 & 6,2 \\
& 12 & 6,55 & 23,5 & 5,30 & 5,2 & 5,4 & 5,5 \\
& 16 & 6,73 & 34,5 & 5,88 & 4,2 & 4,1 & 4,3 \\
\hline \multirow{4}{*}{ Atung } & 0 & 6,15 & 9,6 & 3,36 & 9,0 & 9,0 & 9,0 \\
Powder & 4 & 6,19 & 10,9 & 3,77 & 8,1 & 8,2 & 8,2 \\
& 8 & 6,27 & 13,4 & 4,02 & 7,4 & 7,6 & 7,5 \\
& 12 & 6,31 & 15,1 & 4,30 & 6,7 & 6,9 & 6,6 \\
& 16 & 6,41 & 18,5 & 4,90 & 6,1 & 6,3 & 6,1 \\
Atung & 20 & 6,48 & 21,2 & 5,48 & 5,3 & 5,5 & 5,3 \\
\hline Solution & 0 & 6,15 & 9,6 & 3,36 & 9,0 & 9,0 & 9,0 \\
& 4 & 6,17 & 11,2 & 3,60 & 8,3 & 8,3 & 8,4 \\
& 8 & 6,21 & 12,1 & 3,90 & 7,5 & 7,6 & 7,7 \\
& 12 & 6,34 & 14,2 & 4,17 & 6,7 & 6,9 & 7,0 \\
& 16 & 6,40 & 17,6 & 4,77 & 6,0 & 6,2 & 6,4 \\
& 20 & 6,45 & 20,1 & 5,23 & 5,5 & 5,8 & 5,7 \\
\hline
\end{tabular}



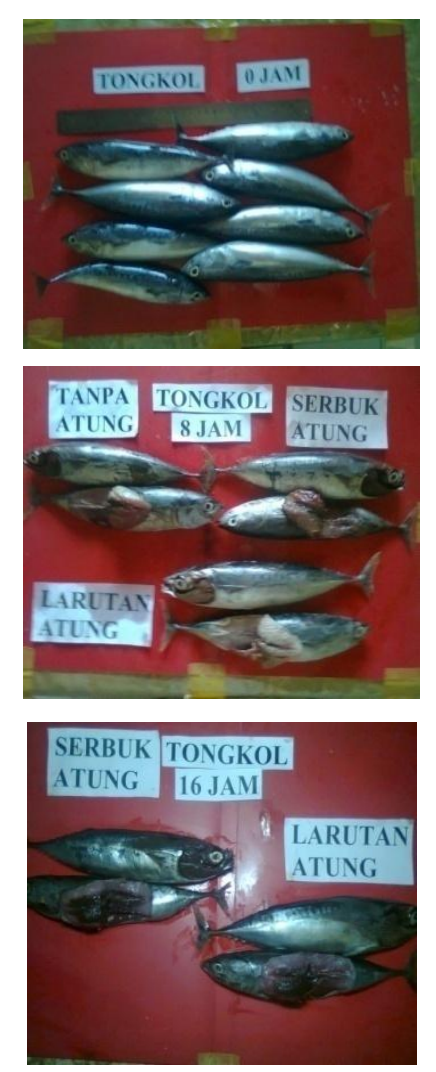
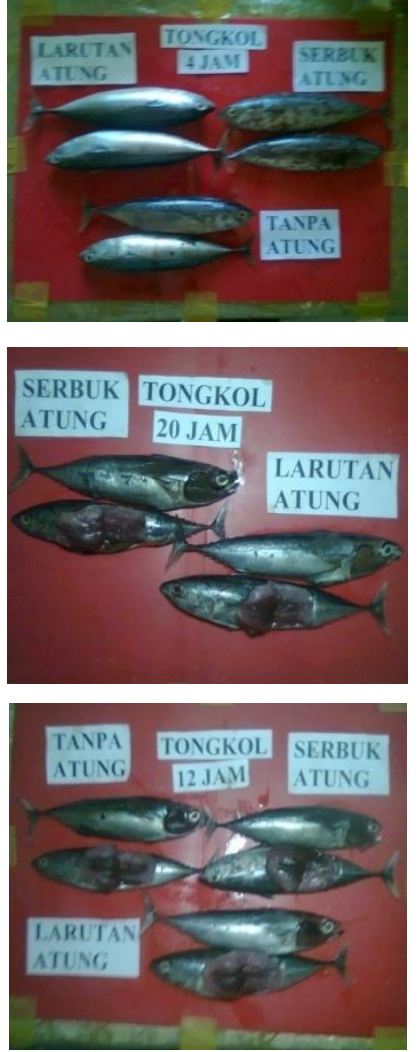

Figure. 2. Deterioration of Quality of Tongkol Fish (Organoleptic Assay)

Tabel 4. Table 2. Analysis of Quality of Kembung Fish.

\begin{tabular}{cccccccc}
\hline Treatment & $\begin{array}{c}\text { Observation } \\
\text { (Hour) }\end{array}$ & $\mathrm{pH}$ & $\begin{array}{c}\text { TVB } \\
(\mathrm{mgN} \%)\end{array}$ & $\begin{array}{c}\text { TPC } \\
(\log \text { X) }\end{array}$ & $\begin{array}{c}\text { Appea } \\
\text { rance }\end{array}$ & odor & Texture \\
\hline \multirow{5}{*}{ Control } & 0 & 6,11 & 8,4 & 3,15 & 9.0 & 9,0 & 9,0 \\
& 4 & 6,30 & 13,4 & 3,84 & 7,6 & 7,4 & 7,6 \\
& 8 & 6,40 & 20,1 & 4,84 & 6,7 & 6,5 & 6,6 \\
& 12 & 6,47 & 23,5 & 5,22 & 5,8 & 5,6 & 5,4 \\
& 16 & 6,64 & 31,9 & 5,78 & 4,6 & 4,5 & 4,6 \\
Atung & 0 & 6,11 & 8,4 & 3,15 & 9,0 & 9,0 & 9,0 \\
Powder & 4 & 6,15 & 10,5 & 3,65 & 8,4 & 8,3 & 8,3 \\
& 8 & 6,27 & 12,6 & 4,30 & 7,8 & 7,6 & 7,6 \\
& 12 & 6,30 & 14,6 & 4,70 & 7,2 & 7,0 & 7,1 \\
& 16 & 6,37 & 17,6 & 4,90 & 6,3 & 6,1 & 6,3 \\
& 20 & 6,40 & 20,2 & 5,15 & 5,6 & 5,5 & 5,5 \\
Atung & 0 & 6,11 & 8,4 & 3,15 & 9,0 & 9,0 & 9,0 \\
Solution & 4 & 6,14 & 9,2 & 3,47 & 8,3 & 8,5 & 8,2 \\
& 8 & 6,23 & 11,7 & 4,02 & 7,9 & 8,1 & 7,9 \\
& 12 & 6,27 & 14,3 & 4,30 & 7,4 & 7,6 & 7,3 \\
& 16 & 6,31 & 15,9 & 4,62 & 6,8 & 7,1 & 6,9 \\
& 20 & 6,36 & 19,3 & 5,11 & 5,9 & 6,1 & 6,0 \\
\hline
\end{tabular}



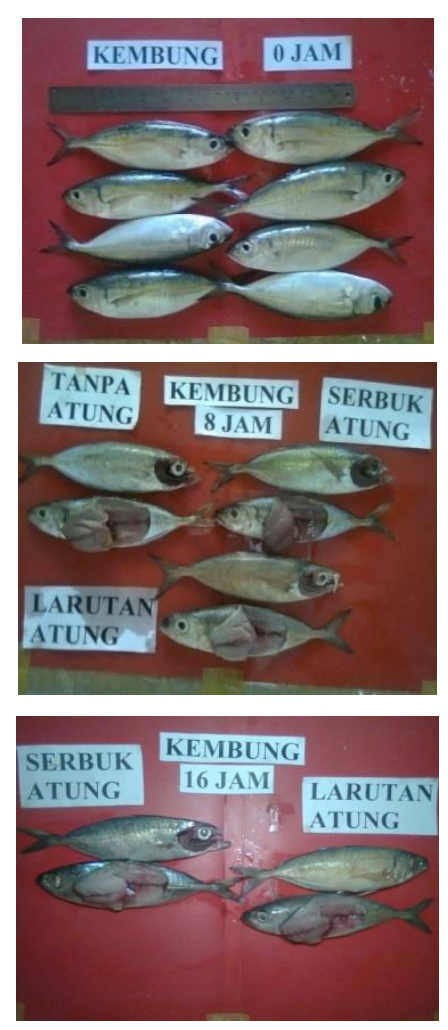
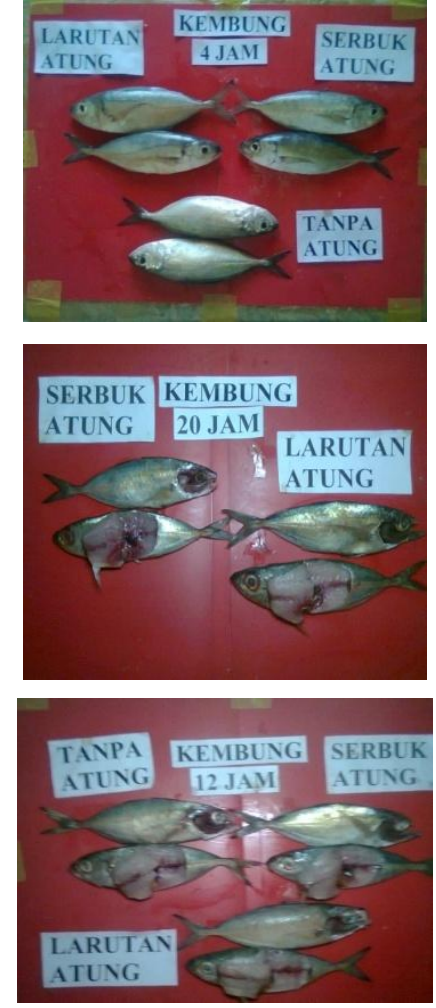

Figure. 3. Deterioration of Quality of Kembung Fish (Organoleptic Assay)

Analysis of the quality of fresh fish served at the table in figure showing that Layang fish freshness without preservatives atung age is 9 hours, while using fish powder and solution atung life is 17 hours. Layang fish without treatment atung panelist to 12 hours (13 hours post catch) with such values appearance 4,6 ; odor 4,4 and texture 4,7 (rejection limit for fishery products is based on the value of 5); $\mathrm{pH}$ values 6.53 ; TVB $32,7 \mathrm{mg} \mathrm{N} \%$ and TPC 5,82 (log X) or $6.61 \times 10^{5}$ colony $/ g$. In line with the decline of the level of freshness of fish Layang than Tongkol decreased with increasing observation time. Tongkol fish freshness age was 13 hours while the powder and solution treatment freshness atung life was 21 hours. Tongkol fish without atung, panelist rejected hour to 16 with such values appearance 4,2: odor 4,5 and texture 4,6.Mean while Kembung fish freshness without atung life is 13 hours, while the powder and solution treatment atung freshness age 21 hours. Kembung fish without atung rejected panelist the 16 th with a value appearance 4,6 in such appearance 4,6 ; odor 4,5 ; texture 4,6 ; $\mathrm{pH}$ values 6.64; TVB 31,9 mg N\% and TPC 5,78 $(\log X)$ or $6.03 \times 10^{5}$ colony $/ \mathrm{g}$.

A number of factors affect the quality of fresh fish including: type and size of fish, biological conditions, season, fishing area, how to capture, water temperature and post catch handling. Quality deterioration pattern above three types of fish are affected by the size. Because of the size of the average fish Layang $85 \mathrm{~g} /$ tail, Tongkol $150 \mathrm{~g} /$ tail and Kembung $100 \mathrm{~g} /$ tail. Size large fish quality deterioration process is slow. Shelf life of fish without the use of treatment Atung following: Layang was 9 hours, Tongkol and Kembung were 13 hours. Tuna fish turned out to be shorter than the shelf life of Kembung due to biological condition 
and the type of fish. llyas stated that handling the fish after catching determined by the type, size and bilogical conditions. Handling of fish without the use of ice caused the decline of the quality of fish. Atung use powder or solution effectively inhibit the rate of deterioration of quality fish, where fish Layang 17 hours while the shelf life Tongkol and Kembung were 21 hours. Moniharapon reported that Sunu fish including species of reef fish with an average weight of $200 \mathrm{~g}$, shelf-life was 36 hours. It was further reported that there was no investment flies in the drying process of Tunny fish (dry salted) with standart atung spraying solution (without dilution). Spraying a solution of the standart Atung Tunny fish freshness fresh cause life is longer than without atung. Use atung fruit seeds as food preservatives have been shown because it contains bioactive components. Bioactive components can kill several types of bacteria and pathogen destroyer food. Atung bioactive components that aselac acid which can kill pathogenic bacteria and food that is destructive. Previously, application usage in handling atung of Windu shrimp can extend the life of freshness. Based on the $\mathrm{pH}$ value, it was explained that the three types of fish declined sequently panelists: Layang fish without atung at 12 th hour while the use of atung at the 20 th hour with a $\mathrm{pH}$ value $\mathrm{pH}$ values 6.40 6,53; TVB $28,8 \mathrm{mg}-33,4 \mathrm{mg} \mathrm{N} \%$ and TPC 5,62 - 5,82 (log X) or 4,17 x $10^{5}$ colony/g - 6.61 $\times 10^{5}$ colony/g. Tongkol fish without atung was 16 hours with $\mathrm{pH}$ values $6.73 ;$ TVB $34,5 \mathrm{mg}$ $\mathrm{N} \%$ and TPC $5,88(\log X)$ or $7,59 \times 10^{5}$ colony/g. While as, Kembung fish without atung was 16 hours with. pH values 6.64; TVB 31, mg N\% and TPC 5,78 $(\log X)$ or 6,02 x $10^{5}$ colony/g.

llyas stated that the decline of the quality of the fish was followed by an increase in $\mathrm{pH}$ value.. Generally, no fresh fish have $\mathrm{pH}$ values higher than fresh fish. This is due to the onset of compounds such as alkaline. llyas said that the fresh fish is a standart rejection TVB value whereas for frozen fish products is $25 \mathrm{mg} \mathrm{N} \%$. Furthermore, llyas argued that the rejection limit is the value of fresh produce at TVB $35-45 \mathrm{mgN} \%$. TPC standart for fishery products must not exceed $5 \times 10^{5}$ colony $/ \mathrm{g}$.

\section{CONCLUSION}

Shelf life of Layang fish without atung only 9 hours after catch. While Tongkol and Kembung fish 13 hours. Panelists rejected at the 16 observation hours (17 hours post capture). Shelf life of Layang fish with the atung powder or solution wan 17 hours. Rejection panelists at the 20 th hour observation (21 hours post capture). Panelists have not been rejected.

Study of the effectiveness of using a solution based on shelf life atung powder needs to be done and Further research with the use atung solution with a lower concentration of $20 \%$ $(10$ and $15 \%)$ needs to be done. 


\section{REFERENCES}

Anonymous, 1980. Standar Ikan Tuna. Di dalam Standarisasi Departemen Perdagangan RI. Jakarta.

Anonymous, 1994. Standar Nasional Indonesia ( S N I) Kumpulan Standar Metode Pengujian Mutu Hasil Perikanan. Direktorat Jenderal Perikanan. Balai Bimbingan dan Pengujian Mutu hasil Perikanan. Jakarta.

Connell, J.J. 1975. Control of Fish Quality. Fishing News Book Ltd. London.

Hadiwiyoto, S. 1993. Teknologi Pengolahan Hasil Perikanan. Jilid I. Fakultas Teknologi Pertanian Universitas Gajah Mada. Penerbit Liberty, Yogyakarta.

Ilyas, S. 1983. Teknologi Refrigerasi Hasil Perikanan. Jilid I. Teknik Pendinginan lkan. CV. Paripurna, Jakarta.

Moniharapon, T. 1993. Biji Buah Atung (Parinarium glaberimum, Hassk) Sebagai Pengawet Udang Windu Segar. Vol. 3 No. 2. Jurnal Ilmu Pertanian Indonesia. IPB, Bogor.

Moniharapon, T. 1998. Kajian Fraksi Bioaktif dari Buah Atung (Parinarium glaberimum, Hassk) Sebagai Bahan Pengawet Pangan. Disertasi Program Studi Ilmu Pangan Program Pasca Sarjana IPB, Bogor..

Moniharapon, T. 2004. Purification and Identification of Antibacterial Compound of Atung (Parinarium glaberimum, Hassk) Seed. Pakistan Journal of Biological Sciences. Volume 7 Number 10. October 2004. ANSInet

Moniharapon, T. 2005a. Inhibition of Food Pathogenic Bacteria by Azelaic Acid. Pakistan Journal of Biological Sciences. Volume 8 Number 3. March 2005. ANSInet.

Moniharapon, T. 2005b. Sensory Quality Study on Post Harvested Fresh Sunu Fishes (Melichthys niger) Kept in Atung Fruit (Parinarium glaberimum, Hassk) and Ice. In. Proceeding of International Workshop Eco-Friendly Coral Reef Fisheries. Ambon, 17 19 March 2005.

Moniharapon, T., F. Pattipeilohy, R.B.D. Sormin dan F.F. Gaspersz. 2006. Aplikasi Penggunaan Atung (Parinarium glaberimum, Hassk) pada Penanganan Paska Tangkap dan Bahan Baku Ikan Olahan di Maluku, kerjasama Lembaga Penelitian Unpatti dengan Dinas Perikanan dan Kelautan Provinsi Maluku.

Rehbein, H; E. Martinsdottir, F. Blomsterberg, G. Valdimarson and J. Oehlensclaeger. 1994. Shelf Life of Ice Redfish, Sebastes marinus and S. mentella. Int. J. Food. Sci. Tech. $29: 303-313$. 